\title{
ENTREVISTA COM NELSON GRABURN
}

Nelson Graburn concedeu a presente entrevista em Buenos Aires, Argentina, no dia 27 de setembro de 2007, no decorrer do período, julho a novembro de 2007, em que ele esteve, como professor visitante estrangeiro, com bolsa da Capes, no Programa de Pós-Graduação em Antropologia Social, da Universidade Federal do Rio Grande do Sul. Nelson Graburn foi professor da Universidade da Califórnia, em Berkeley, de 1964 a 2007, quando se aposentou, aos 70 anos de idade. É conhecido como um dos pioneiros e mais importantes estudiosos do turismo na área da antropologia no mundo. Seus interesses de pesquisa abarcam, além do turismo, temas como parentesco, arte, museus, etnologia e Oriente, especialmente Japão e China. Na entrevista ele narra um pouco sobre sua vida pessoal e profissional e o processo pelo qual foi se interessando e agregando seus temas de pesquisa. Horizontes Antropológicos agradece particularmente a Rodrigo de Azeredo Grünewald pela condução desta entrevista. Rodrigo de Azeredo Grünewald é professor da Universidade Federal de Campina Grande e fez seu estágio de pós-doutorado em 2005-2006, na Universidade da Califórnia, Berkeley, sob a supervisão de Nelson Graburn.

Rodrigo Grünewald: Professor Graburn, você gostaria de comentar algo sobre sua infância ou adolescência que você acha importante e que tenha influenciado sua futura carreira em antropologia? Onde você nasceu e como era sua vida na Inglaterra? O que foi determinante para o seu futuro como antropó$\log 0$ ?

Nelson Graburn: Eu nasci em Londres, em 1936, de uma mulher solteira que imediatamente me deu para uma instituição de adoção e desapareceu. Eu não sabia quem era meu pai, mas soube que ele já tinha se casado com outra mulher. Então, fui colocado num orfanato onde fiquei por cerca de um ano, até que meus pais, que eram bem mais velhos, vieram adotar uma criança - minha mãe tinha 36 anos e meu pai 56. Minha mãe contou que meu pai estava muito inseguro em ter um filho, pois já tinha 56 anos e não queria ter trabalho com um bebê pequeno. Mas, quando eles chegaram lá, eu sorri para ele e tentei tocá-lo - e não a minha mãe - e então ele disse: “oh, então talvez seja legal” [risos]. 
Então, eles me adotaram. Meus pais passaram a maior parte de sua vida adulta na Malaia, ${ }^{1}$ especialmente meu pai, que passou 27 anos lá, trabalhando em uma companhia de fusão de estanho. Minha mãe apenas foi para lá 28 anos depois de meu pai. Ela era muito mais jovem e ficou com um tio que era um alto comissário em Cingapura. Então ela conheceu meu pai. Ela tinha 28 anos e ele 48 quando se casaram. Eles moraram na Malaia até 1933, quando meu pai se aposentou e voltou para a Inglaterra. Então eu nasci e fui adotado depois que meu pai já tinha se aposentado. Mas, a maior parte da família dele, a irmã e o irmão mais velho e um mais novo, todos passaram sua vida adulta na Malaia ou no Oriente. Isso imediatamente conectou muitos jovens britânicos com outras pessoas no Império, falando línguas e convivendo com culturas diferentes. A irmã mais velha de meu pai casou-se com um jovem que tinha vindo para a Inglaterra, para Londres, para estudar direito e eles tiveram que ajudar o Império. Quando Gandhi foi para a África do Sul, meu tio foi para Hanói, que é uma ilha da China onde estava a sede do comércio britânico. Então, eles foram em 1896 e, em 1900, foram para Cingapura e Malaia, e convidaram todos os irmãos para irem morar lá com eles. Então, a família inteira viveu na Malaia ou em Cingapura. E quando eu cheguei, muitas coisas na minha casa eram da Malaia. Meus pais falavam malaio e minha mãe não entendia porque eles se xingavam em malaio quando brigavam. Quando meu tio chegou, eles também falavam em malaio. Então, acho que eu fui um tipo de britânico/malaio, enquanto outras pessoas britânicas como minha avó ou funcionários do governo não sabiam falar malaio e não sabiam nada sobre o lugar. Então, eu sou fruto de uma natureza especial de diferenças culturais e, quando fui para a escola, aos oito anos, descobri outros meninos que tinham outras conexões com outros lugares no mundo. Talvez eles pensassem que fizessem parte da África do Sul ou de outro lugar no Império. Muitas pessoas na escola ou seus pais tinham vivido nesses lugares, e também estavam num internato onde tinham aulas, então havia uma grande conexão com diferentes partes do mundo. Eu me lembro, quando era garoto, de ouvir velhas histórias sobre nativos. Eu via fotos de nativos nos álbuns e livros dos meus pais, e eles descreviam como os nativos eram pessoas maravilhosamente talentosas, que tinham uma estética muito bela, 1 Neste trecho da entrevista Graburn mantém a designação de "Malaia” à região, porque na época
ainda não existia a Malásia como país.

Horizontes Antropológicos, Porto Alegre, ano 14, n. 29, p. 341-368, jan./jun. 2008 
que cantavam bem e tinham belas vozes, que podiam correr e trabalhar muito, etc. E na Inglaterra daquele tempo outras pessoas que tinham passado algum tempo fora do país chegavam para meus pais e diziam: “Oh, Cecily”, que é o nome da minha mãe, "o que são esses nativos na cozinha, eles são sujos”. Ao que ela respondia: "Não, você pode aprender a cozinhar muito bem com eles". Ou diriam, como me lembro de um homem que disse ao meu pai: "Diga-me, Henry. Um chinês é um homem de verdade?”, pois ele nunca havia saído da Inglaterra, e então pensava que um chinês era uma espécie de macaco ou algo do gênero. Então meus pais estavam sempre defendendo os nativos de todo tipo de preconceito dos ingleses. O que é interessante, pois sempre se ouve que as pessoas que governavam o Império eram extremamente racistas e preconceituosas, mas na Inglaterra havia, por outro lado, pessoas que nunca foram simpáticas ao Império e estavam misturadas com outras pessoas muito mais preconceituosas. Elas pensavam que os nativos estavam num ponto diferente da escala de evolução. Então, de algum modo, os nativos costumavam me acompanhar e com eles eu podia correr descalço, ver coisas maravilhosas, ouvir os pássaros, etc. Então achei ótimo ser um nativo. Eu também ouvia histórias de que às vezes os nativos não se davam bem com as bebidas alcoólicas, pois ficavam facilmente bêbedos e coisas assim. Assim, me vi interessado no que estava acontecendo ao redor do mundo, em outras línguas.

Rodrigo Grünewald: E quanto ao colégio e de quando você decidiu se tornar antropólogo?

Nelson Graburn: Bem, outra coisa que acontecia na minha escola é que nós éramos forçados a aprender o latim e o grego. E a gente não aprendia apenas a linguagem. Aprendíamos peças de teatro e poemas, e toda a civilização. Então, lembro-me de um antropólogo dizer que existia um outro jeito de conhecer realmente uma civilização. E isso foi até eu ter 14 anos. Depois eu mudei para ciências naturais, de que eu realmente gostava, e fui para Cambridge, onde consegui uma bolsa de estudos. Numa das casas em que morei, um rapaz do quarto ao lado estava estudando antropologia. Então ele me pediu para ajudálo a preparar-se para os exames. Assim eu comecei a ler livros de antropologia e achei interessante. Eu não entendia por que eu estava estudando aquilo, mas achei que deveria tentar. Depois do final de meu segundo ano, depois de passar nas provas, tive outro ano em que poderia estudar o que quisesse. Então decidi estudar antropologia no terceiro ano e quis conhecer Edmund Leach. Ele me 
convidou para participar, gostei e fui assistir aulas e ouvi muita gente, e ele e um de seus alunos de graduação tornaram-se meus tutores. Eu lia um livro toda semana, escrevia ensaios e discutia com eles, etc. Então me decidi pela antropologia.

Rodrigo Grünewald: Você tinha algum interesse específico naquela época?

Nelson Graburn: Bem, é difícil dizer o que são interesses conscientes ou subconscientes. Por exemplo, algumas pessoas costumavam me provocar dizendo que eu estava interessado em parentesco e estrutura social porque eu tinha sido adotado e estaria procurando minha família perdida... Eu estudei parentesco na Pós-Graduação tanto na Universidade McGill (Canadá) quanto na Universidade de Chicago por muitos anos. Eu tinha um interesse especial em família. Mas eu não tinha um interesse específico. Acho que me interessava saber sobre pessoas que viviam de um modo diferente, que faziam coisas extraordinárias ou eram caçadores, falavam outras línguas. Acho que isso é um jeito de olhar para frente e provavelmente muita gente na Inglaterra sentia que, se tivesse oportunidade, era isso que gostaria de fazer. Por exemplo, meu primo fez McGill comigo e, logo que terminou a graduação, estudando línguas modernas ou algo do gênero, foi para o Brasil trabalhar para o Banco de Londres na América do Sul, em Recife, Ele ficou lá durante 14 anos. Agora ele mora na Inglaterra e sente saudades do Brasil. Ele ainda visita o Brasil. Então acho que muitas pessoas na Inglaterra têm essa idéia de se engajar com o restante do mundo. Não é preciso ser antropólogo nem estar arruinado para gostar de conhecer outras pessoas e outros lugares. Então as pessoas se engajavam em várias missões. Muitas outras pessoas na antropologia tiveram conexões ou experiências, como o próprio Edmund Leach. Ele veio de uma família que tinha negócios na China. Então, na infância, ele ouviu sobre a China e, quando se tornou adulto, decidiu ir para lá. Ele tinha estudado matemática e engenharia e então foi chamado de volta durante a guerra.

Rodrigo Grünewald: Você decidiu trabalhar enquanto estava na universidade na Inglaterra?

Nelson Graburn: Não, não era preciso trabalhar. Não mesmo. Era apenas o terceiro ano de graduação, um ano em que estudei apenas antropologia, nada além de antropologia. 


\section{Rodrigo Grünewald: E depois disso?}

Nelson Graburn: Depois disso, eu não sabia o que eu iria fazer, mas naquela época na Inglaterra havia o Serviço Militar Nacional compulsório - e eu tinha participado de treinamento militar enquanto estava na escola média. Foi na artilharia, quando tínhamos uma arma para praticar. Naturalmente eu não tive que ir para o exército e me tornar um oficial, mas tive que me formar na universidade. Então eu teria que me alistar no exército e ir para algum lugar no Império. Eu preferia estudar antropologia e estudar nativos em vez disso. Eu perguntei ao Leach se eu poderia ir para a faculdade ou algo do gênero para me livrar do exército britânico e ele me disse: "bem, você precisa esperar pelas provas do final do ano. Se você se sair bem, eu posso arrumar um lugar como a Austrália ou algo do tipo para você ir”. Mas eu não consegui esperar e escrevi para todas as faculdades ao redor do mundo me candidatando para estudar antropologia. Fui aceito na McGill University, em Montreal (1958-1960), e meu primo, que era mais novo do que eu, também foi aceito lá, mas na graduação, então foi legal. A McGill me ofereceu uma bolsa que me fez escolher entre o sistema de ensino e o sistema de pesquisa. Então eu fiz algum dinheiro, assim como meu primo, e embarcamos no navio rumo ao Canadá exatamente no momento em que eles estavam fazendo alistamento para o campo de treinamento no exército, ao que meu pai respondeu simplesmente: “Meu filho está estudando fora”. Então eu não poderia voltar para a Inglaterra até que o Serviço Nacional terminasse, sob risco de ser considerado desertor. Tive que ficar fora da Inglaterra e, durante esse período, minha mãe morreu e eu não pude voltar para vê-la. Era 1960. Eu não voltei para a Inglaterra até 1963. Foi a primeira vez que eu voltei desde que havia partido em 1958.

Rodrigo Grünewald: E o seu interesse pelos inuit começou nessa época?

Nelson Graburn: Começou, sim, na McGill, quando eu estava no Canadá.

Rodrigo Grünewald: E no começo você se interessou por organização social ou artes?

Nelson Graburn: Foi pela estrutura do parentesco. Eu naturalmente acho religiosidade e simbolismo muito interessantes. Talvez algumas coisas sobre lingüística também. Mas eu não tinha idéias específicas quando fui para a McGill. 
Entre as oportunidades de estudar no Canadá, uma possibilidade era estudar os indígenas mohawk na reserva Caughnawaga. Fui para a reserva algumas vezes e conversei com as pessoas. Outra possibilidade, que alguém me sugeriu, era estudar os franco-canadenses, pois havia um professor que estudava os franco-canadenses. Ambos os professores eram antropólogos neste departamento em que muitos sociólogos se interessavam pelo Norte. Um deles tinha feito alguns trabalhos no Ártico e outro fez uma pesquisa sobre aculturação e o fato de o governo ter começado a ir para o Ártico para instalar serviços sociais. Então fui persuadido que era uma boa coisa a fazer e fui apresentado a um pesquisador do governo que tinha enviado várias pessoas para fazer trabalhos durante o verão no Canadá. Naquela época, fiquei sabendo que a instituição mandava mais pesquisadores a campo do que qualquer outra no mundo. Mais do que os museus, do que a Smithsonian, porque o governo queria que antropólogos fossem para todos esses lugares, lugares indígenas e inuit, onde estava começando a chegar para instalar escolas, clínicas e programas de moradia para os nativos. Para isso, eles queriam que estudos de comunidade fossem feitos. Então fui lá num verão para estudar uma comunidade sobre a qual eu escrevi meu ensaio para a McGill e, no verão seguinte, fui trabalhar numa outra comunidade, onde fiz um estudo similar para o governo que era a aplicação pura da antropologia. Depois, fui para a Universidade de Chicago. Eu não pretendia ir para os Estados Unidos, mas, quando voltei para a McGill, fiquei sabendo que não poderia fazer um $\mathrm{PhD}$ em antropologia porque eles tinham apenas $\mathrm{PhD}$ em sociologia, o que eu não compreendia. Eu achei que poderia escolher entre antropologia e sociologia. Então, eu disse para o chefe de departamento: "Eu cruzei o Atlântico por nada? Para conseguir um diploma de mestrado e não de doutorado?” Além disso, havia apenas um departamento no Canadá que oferecia $\mathrm{PhD}$ em antropologia na época, a Universidade de Toronto, que não era muito boa. A maioria dos professores da McGill eram americanos ou tinham sido formados nos Estados Unidos, pois havia pouquíssimos cursos no Canadá. Eles me convenceram e eu escrevi para uns dez lugares para me candidatar. Fui classificado e consegui bolsas em Yale, Cornell e na Universidade de Chicago. Um dos meus professores foi para Yale, e outro para Cornell. E todos os sociólogos disseram que eu deveria ir para a Universidade de Chicago, que era a melhor. Então eu escolhi a Universidade de Chicago (1960-1963) e tive muita sorte, não apenas porque encontrei professores como Sol Tax, Fred Eggan, Julian Pitt-Rivers, Norman McQuown, como também pelos jovens que chegaram da Universidade da Califórnia exatamente na mesma época que 
eu, Clifford Geertz, David Schneider, Lloyd Fallers, formando um grupo de pessoas que fez de lá um lugar muito excitante. Eu tinha uma bolsa e, depois de um ano, comecei a trabalhar. Eu trabalhei para o projeto sobre parentesco de David Schneider, que era um estudo comparado de pessoas comuns em Chicago e Londres. Raymond Firth era o responsável pela pesquisa em Londres e David Schneider pela pesquisa nos Estados Unidos. Eu trabalhei para eles por dois anos e meio para fazer um dinheiro além da bolsa. Na verdade, fui para a Inglaterra na mesma época em que Schneider foi participar de uma conferência entre a parte americana e a inglesa desse estudo. Raymond Firth estava lá e seus assistentes na pesquisa eram Anthony Forge e Jane Hubert, que se tornariam grandes antropólogos depois. Eu estava para conseguir o $\mathrm{PhD}$, quando disse para Raymond: "Bem, vou conseguir meu $\mathrm{PhD}$ em Chicago em seis meses e quais são as minhas chances de conseguir um emprego na Inglaterra ou no Reino Unido? Eu gostaria de voltar para o lugar de onde eu vim. Estive em Cambridge.” E ele disse: "Bem, a menos que alguém morra, eu não acho que haverá uma vaga nos próximos cinco anos.” As coisas são lentas na Inglaterra. Uma vaga em cinco anos. Então, desisti de conseguir um emprego na Inglaterra. Então eu fiz um pós-doutorado na Northwest University, com um professor que dava aula lá e na Universidade de Chicago. Eles enviaram cerca de 15 jovens antropólogos para diferentes partes do mundo onde já tinham sido feitas experiências de campo para estudar a natureza das fronteiras, particularmente em situação pré-coloniais ou não-coloniais. O que fazia as pessoas se tornarem inimigas ou amigas? Tínhamos que estudar ambos os lados das fronteiras. Eu passei um ano estudando as fronteiras entre os índios naskapi e o outro lado inuit, que sempre foram inimigos tradicionais. Eu estava muito interessado em etnologia e em trabalhar com os inuit. Quando estava no Ártico, não tinha nenhum equipamento sofisticado, telefone, etc.

\section{Rodrigo Grünewald: Como você chegou a Berkeley?}

Nelson Graburn: Quando eu estava trabalhando para Schneider, no projeto sobre parentesco, um dia alguém me disse: "Dois professores de Berkeley estão chegando aqui. Eles gostariam de entrevistar algumas pessoas. Você não quer fazer a entrevista?” Eram David Mandelbaum e Ted McCown, ambos professores de Berkeley. Eles estavam voltando da reunião da Associação Americana de Antropologia, provavelmente de trem. Vinham a Chicago e pensaram em fazer entrevistas para ver se contratavam alguém, antes de voltar 
para Berkeley. Bem, parece que funcionou, porque seis ou oito meses depois, recebi um telegrama com uma proposta de emprego. Fiquei muito surpreso. David Schneider tinha vindo de Berkeley. O pessoal em Chicago não gostava de algumas pessoas de Berkeley e referiam-se ao antiquado e autoritário George Foster. Então eles disseram: "Bem, nós não gostamos de Berkeley, mas é um lugar agradável para se morar. Então se você for para lá e conseguir uma boa casa nas colinas...” Fui para lá e me dei bem com as pessoas, até com o George Foster. Quando voltei do Ártico em setembro de 1964, peguei minhas coisas em Chicago e fui para Berkeley e comecei a dar aulas em outubro.

Rodrigo Grünewald: Foi na época do movimento dos direitos civis?

Nelson Graburn: Sim, exatamente nessa época. Logo que eu cheguei, houve greves, boicotes, fechamento de universidades e ocupação policial.

Rodrigo Grünewald: O livro sobre parentesco e organização social que você organizou é dessa época?

Nelson Graburn: Exatamente. Eu não acho que o parentesco tenha sido o primeiro tema. Eles sabiam que era um dos meus temas e um dos meus professores da época era Eugene Halton, uma pessoa brilhante que estudava parentesco, e propunha até uma versão matemática do parentesco, com uma abordagem demográfica. Não era um curso de pós-graduação, mas ele tinha estudantes brilhantes. Um artigo de uma estudante dele foi publicado na American Anthropologist, mostrando que Lévi-Strauss estava errado em relação ao parentesco. Era uma estudante chinesa. No ano seguinte, um outro estudante examinou a mesma questão e apresentou no exame final. Esse texto também acabou sendo publicado pela American Anthropologist. Não era nem uma monografia de final de curso, apenas uma prova. Mas era um trabalho brilhante. Parentesco nunca foi um assunto popular, talvez umas 25 pessoas estudassem o tema. Eu dei aulas sobre parentesco por muitos anos, e eram poucos os interessados. Algumas vezes eu dei aulas para turmas de cinco alunos.

Rodrigo Grünewald: Sobre o quê você ministrava aulas em Berkeley nessa época? 
Nelson Graburn: Eu dava aulas sobre a estrutura de parentesco. Eu também escrevi um livro didático que nunca foi publicado. Ainda o tenho. São uns doze ou catorze capítulos, mas nunca foi publicado. Tem um capítulo que eu gostaria de terminar.

Rodrigo Grünewald: Quando e como seu interesse mudou para turismo e arte? Foi primeiro arte ou turismo?

Nelson Graburn: Ah, as artes. Quando voltei do Ártico para McGill, descobri que alguns inuit estavam fazendo pequenas esculturas que vendiam para qualquer branco que aparecesse quando o navio chegava. Chegavam dois ou três navios, às vezes um avião, mas isso era raro. Havia alguns brancos vivendo lá, o administrador e sua esposa, empregado do governo. Havia também dois missionários, um anglicano e outro católico. Então eram oito brancos na comunidade. Os inuit faziam coisas para vender e Companhia de Comércio comprava essas coisas e as mandava para serem vendidas no Sul do Canadá. Então isso se tornou uma fonte de renda para os inuit, além do que eles conseguiam vendendo peles de foca. Às vezes, eles faziam mais dinheiro vendendo peças de arte do que peles de foca, pois os preços das peles tinham caído. O governo estava chegando ao Norte naquela época e estava iniciando um programa de subsídio ao qual todos os nativos tinham direito se tivessem um filho com menos de seis anos. Acho que eles ganhavam oito dólares por cada criança com menos de seis anos. Uma família inuit tinha oito ou nove filhos, então conseguiam bastante dinheiro. O governo também dava um socorro, algo como uma previdência social, para as pessoas muito pobres, que precisavam caçar ou algo do tipo para sobreviver. Quando o clima está muito ruim, ninguém pode sair para caçar e conseguir peles de foca para vender, e então eles vivem do dinheiro do governo. Mas o governo pensou que seria melhor que eles trabalhassem para ganhar esse dinheiro. Então, em vez de dar-lhes o dinheiro, o governo lhes disse "façam esculturas" e passou a comprá-las. Assim, o governo deixou de simplesmente lhes dar dinheiro e passou a fazer com eles trabalhassem para ganhar o dinheiro. O governo também estava economizando impostos, pois pagava às pessoas 20 dólares por uma escultura que talvez seria vendida por 25 ou mais. Quando voltei para Montreal, depois de cinco meses no Ártico, vi que as lojas estavam vendendo essas esculturas e contando histórias fantásticas sobre elas, sobre visões espirituais que os inuit nunca associa- 
ram a elas. Os brancos estavam inventando histórias para vender as esculturas. Nessas esculturas, os brancos projetavam coisas que eles pensavam sobre os nativos. Pensei “isso é detestável”. Quando fui para Berkeley, em 1965, assisti a um programa de televisão, na televisão pública, a PBS, em que uma negociante de arte falou sobre as esculturas inuit que estava tentando vender. Ela não sabia nada sobre os inuit. Então, liguei para a emissora e disse "isso é terrível”, e pedi um tempo igual para os inuit falarem. Eles concordaram, e disseram que me ligariam depois. Bem, depois eu me tornei amigo daquela mulher que era a negociadora de arte. Quando minha mulher e eu fomos para o Ártico estudar especificamente a arte inuit, em 1967 e 1968, tive que deixar Berkeley e minha mulher ensinou um ano em uma escola primária. Tínhamos uma casa subsidiada pelo governo. No final do ano, aquela mulher, a senhora Jaffe, foi com a filha para o Ártico para conseguir alguns objetos de arte. E ela me pagou para acompanhá-la. Eu não fiz o programa de televisão, mas ela mesma aprendeu sobre a realidade dos inuit. Assim, surgiu um interesse antropológico sobre os inuit, seu artesanato, sua fonte de renda. Havia um professor especialista na Nova Zelândia que falava sobre a arte maori e muitas coisas que ele dizia se aplicavam à arte inuit, como os brancos a vendiam e contavam histórias sobre ela, como a argumentação de algumas pessoas era falsa, apenas para vender as peças e alguns detalhes técnicos sobre como eles esculpiam, sobre os instrumentos que usavam também eram falsos. Fiquei muito instigado em saber que algo similar estava acontecendo no outro lado do mundo. Naquele ano, estava lecionando um seminário de pós-graduação sobre cadeias culturais e introduzi o tema. Alguns estudantes foram atrás de mais literatura sobre como a arte primitiva tinha se tornado comercial. Descobrimos que isso era freqüente e que alguns vendiam diretamente para turistas, enquanto a maioria das peças inuit eram exportadas. Não havia turistas, apenas alguns poucos brancos que exportavam as peças que depois eram vendidas para turistas. Isso foi chamado turismo indireto. Quando você compra coisas de um povo, mas na realidade nunca o viu, então se diz que você compra seus espíritos. Isso foi publicado, em 1977, num dos primeiros números de Annals of Tourism Research (Aspelin, 1977). E era um artigo sobre o Brasil. Então, percebi que esse tema bastante interessante estava completamente difundido, mas ninguém tinha pensado muito sobre ele. Na verdade, em muitos lugares havia o interesse a respeito disso por se tratar de arte comercial ou algo do gênero, arte turística. Escrevi para todos os antropólogos do mundo que descobriram quem tinha um 
programa de pesquisa sobre a arte nativa, o que eles estavam fazendo na África, na América do Sul, etc. Eu me propus a dialogar, caso eles quisessem me encontrar ou enviar-me algum trabalho, para podermos conversar sobre o que acontece com essa arte quando turistas se apropriam dela. Que mudanças ocorrem, o que a população local pensa. Entrei em contato com várias pessoas, não apenas americanos, e nos encontramos no congresso da Associação Americana de Antropologia, em San Diego, em 1970. Então, formamos um grupo de pesquisa para examinar os trabalhos e montei um livro sobre o tema. Também pedi para as pessoas que não puderam ir ao congresso que escrevessem alguns capítulos, e assim reunimos muitos textos para o livro.

\section{Rodrigo Grünewald: Ethnic and Tourist Arts?}

Nelson Graburn: O livro foi chamado de um modo diferente no primeiro momento, algo como Art and Social Changes, onde havia publicado um trabalho sobre o tema. As pessoas obviamente ficaram muito interessadas, já que haviam publicado textos nele. Os editores mudaram o título do meu trabalho sem me avisar e o chamaram de Eskimos and Airport Art (Graburn, 1967). Foi a primeira vez que se ouviu o termo "arte de aeroporto", em 1967. As pessoas pensaram que eu é que havia inventado o termo, mas, na verdade, foram os editores. Montamos o livro com os trabalhos preliminares e eu mandei para vários editores, mas ninguém quis publicá-lo.

Rodrigo Grünewald: A “arte de aeroporto” foi o tema que o levou para os estudos sobre turismo?

Nelson Graburn: Não especificamente. Fiquei interessado na comercialização dessa arte. Algumas delas eram arte turística, mas não eram todas feitas para turistas. A maioria dos trabalhos escritos que eu reuni eram sobre vendas diretas para turistas. Alguns eram nativos. Não consegui que ninguém publicasse meu livro e, uma vez, conversando com meu cunhado sobre isso, decidimos chamá-lo de Ethnic and Tourist Art, porque o livro incluía a parte étnica do tema bem como o comércio e o turismo. Algumas artes modernas e étnicas não são feitas para vender, mas são transformadas em ícones ou identidade e servem a múltiplos propósitos: podem ser vendidas, mas também podem preservar tradições. Então eu chamei o livro de Ethnic and Tourist 
Arts: Cultural Expressions from the Fourth World. ${ }^{2}$ Mas, muitas pessoas não tinham nenhuma idéia a respeito do título. O diretor da editora da Universidade da Califórnia me escreveu perguntando: "O que é uma arte turística? Você se refere ao que aquelas senhoras fazem quando vão para Paris e pintam Notre Dame sentadas no banco ou algo do tipo?” Então não era um tema que pessoas da academia soubessem muito a respeito, ninguém lia sobre isso. A coisa mais próxima foi o livro escrito por Julius Lips, em 1937, chamado The Savage hits Back (Lips, 1937). Era um livro sobre como nativos na colônia fazem esculturas de brancos que estavam lá. E isso é um tipo de resistência, o contra-ataque selvagem, e o que se tornou muito popular na arte turística agora é comprar retratos de brancos colonos com seus uniformes e chapéus. Na verdade, depois de passar por 16 editores, a editora da Universidade da Califórnia decidiu publicá-lo e acharam que fizeram um bom negócio. Havia muitas fotos nele. Eu não tinha dinheiro suficiente para muitas fotos coloridas, mas ele foi bem ilustrado.

Rodrigo Grünewald: Como você levou os estudos sobre turismo para a Universidade da Califórnia? Lembro-me que certa vez em Berkeley você me contou da primeira vez que você esboçou um comentário sobre as semelhanças entre turismo e antropologia no campo. Como foi começar a ensinar sobre turismo e convencer as pessoas sobre o interesse dos estudos sobre turismo?

Nelson Graburn: O que aconteceu foi que, em 1974, Valene Smith me convidou para a primeira sessão dos encontros sobre antropologia e turismo da Associação Americana de Antropologia, embora não estivesse estudando turistas na época. Eu estudava a arte turística. Isso foi antes do livro ser publicado, mas ela sabia o que eu estava fazendo. E todas as outras pessoas que foram convidadas, como o excepcional Dennison Nash, estavam escrevendo sobre turismo e turistas. Eu os chamei de "estudos de impacto". Então, o que eu fiz foi ser um comentarista e tentei olhar isso sob o ponto de vista motivacional do turista, focado mais no turista do que no turismo. Na verdade, eu ajudei a

2 É o clássico Ethnic and Tourist Arts. Cultural Expressions from the fourth World (Graburn, 1976). Nelson organizou e escreveu a também clássica introdução: Introduction: The Arts of the Fourth World (Graburn, 1976, p. 1-32).

Horizontes Antropológicos, Porto Alegre, ano 14, n. 29, p. 341-368, jan./jun. 2008 
organizar o livro e escrevi a introdução e um ensaio que foi incluído na única parte escrita pelos estudantes, chamada "Estou estudando macacos", que é feito quando se rastreia turistas. E, sem me dizer, ela não usou o ensaio no livro e cortou a maior parte do que eu tinha colocado na introdução, porque não fizemos juntos. Os alunos me ajudaram a fazer cópias de todo o material e as usamos nas aulas de turismo. Na mesma época, talvez em novembro de 1975, eu vi cópia do livro de Dean MacCannell, chamado The Tourist (MacCannell, 1976). Ele não estava à venda, ainda, mas eu o vi e achei interessante. Quando comecei a lecionar o curso sobre turismo em 1976, usei o livro de MacCannell, que era muito bem explicado e tinha um tanto de turismo ocidental, e usei esse livro na sua forma preliminar para organizar os estudos. As pessoas diziam esse assunto que era bobagem, perda de tempo. Elas não achavam que o turismo era sério ou um tema importante. Mas, deixaram, mesmo assim, eu fazer um experimento. Disseram: "Nós deixaremos que você faça isto uma vez e nós chamaremos um número regular.” Então, dei uma aula para cerca de 170 estudantes. Esperava uns 40. Tive, então, uma grande sala e um assistente, que era um dos meus alunos da pós-graduação. A coisa ficou animada. Consegui que algumas outras pessoas se interessassem e organizei minissimpósios com um especialista de cada área para falar sobre suas leituras. Por exemplo, sobre as montanhas peruanas, convidei John Rowe e Pat. ${ }^{3}$ Rowe, claro, é o mais famoso antropólogo e arqueólogo desse assunto e Pat estudava os índios da área. Contei também com a participação de Ochoa, ${ }^{4}$ que tinha sido antropólogo da Universidade de Cuzco e estuda turismo desde então. Eles eram especialistas sobre o desenvolvimento do turismo em Cuzco, onde estive com Kathy ${ }^{5}$ anteriormente. Num outro painel, participaram dois estudantes e um visitante no Departamento de Antropologia de Berkeley, da Tailândia. Eles eram especialistas em turismo na Tailândia, que começava a se tornar popular entre os turistas. Eu e Kathy visitamos o país em 1974 e sabíamos sobre ele. Então, pude mostrar minhas fotos e filmes, que os alunos viam e depois debatiam. Isso se tornou muito excitante. Não me lembro quais eram, talvez dois ou três desses trabalhos, eu tive pessoas da área respondendo questões e debatendo sobre o

\footnotetext{
Patrícia Lyons, esposa de Rowe.

4 Jorge Flores Ochoa.

5 Sua esposa Katherine Graburn.
} 
desenvolvimento do turismo. De qualquer forma, as pessoas concordaram com as aulas regulares que eu poderia dar. Chamei MacCannell, que na época em que li o seu livro ele estava na universidade (Berkeley). Acho que isso foi temporário. Ele pediu-me que escrevesse uma carta de apresentação para ele conseguir um emprego na Universidade da Califórnia, em Davis. Ele conseguiu o trabalho e desde então temos estado próximos. Eu acho que algumas vezes nós temos algo em comum. Acredito que o livro de MacCannell nos levou a considerar o turismo antropológico e a exploração ocidental como um todo e a questionar as coisas que viriam.

Rodrigo Grünewald: E a respeito desses 33 anos lecionando e atuando em arte turística, turismo e estudo de arte em Berkeley e outros lugares do mundo?

Nelson Graburn: Na verdade, tive muita sorte. O editor da revista da Unesco, a revista Internacional Social, ouviu falar do meu ensaio sobre artes turísticas e étnicas antes de o livro ser publicado porque eu tinha escrito outro artigo em algum outro lugar. Ele pediu-me outro artigo, que foi publicado na revista da Unesco em quatro línguas, acho que em inglês, francês, alemão e espanhol. Então, alguns anos mais tarde, ele me escreveu de volta e disse: "Você tem um outro artigo sobre aquele assunto? Estava muito bom. Poderia me dizer o que está acontecendo agora que você está estudando essas artes?” E eu escrevi: "Na verdade, eu apenas comecei a ensinar turismo e nunca tinha feito isto antes. Gostaria de saber sobre isto?” E ele disse: “Oh, meu Deus. Eu nunca soube que você estava ensinando turismo.” Então, escrevi um artigo para eles sobre o ensino de antropologia e turismo, sobre como eu comecei o curso, que tipo de estudantes o procuravam, que livros eu usei. Na verdade, tive que explicar sobre o sistema universitário americano porque sabia que muitas pessoas não o conhecem. Esse artigo foi publicado na revista, em 1979, em cinco línguas. Adicionei outras, talvez russo. Desde então, encontro pessoas que me dizem: "Obrigado por aquele artigo. Fui capaz de mostrar na minha universidade e dizer: isso é sério, ensinar sobre turismo. Vamos estudar turismo também.” Ouvi de pessoas da América Latina, da Î́ndia, de todos os lugares. Foi muito bom e ajudou a criar consciência de sobre algo que estava apenas começando. Havia o livro do MacCannell e da Valene Smith, ambos publicados em inglês. Mas esses artigos de periódicos estão em todos os lugares, poderiam ser muito bem distribuídos, não temos que comprá-los. Eles se espalham. O 
estudo de arte turística e étnica e o estudo do turismo ainda estão muito presos ao mundo anglo-saxão, muito dominado por um certo grupo de anglófilos que tentam fazer algo a respeito. Meus livros estão no Japão. Tudo aconteceu ao mesmo tempo. Fui para lá em 1974. Tive um ano sabático e em dois meses viajei para a Ásia com minha mulher, minhas duas filhas e minha sogra. Fomos ao Japão por um mês e ficamos no campo, na casa da família da minha sogra. Ficamos em Tóquio com amigos por uma semana e fomos ao Sudeste da Ásia, para Hong Kong, Malásia, Cingapura e Bancoc. Por isso, eu conhecia Bancoc. Estive lá como turista em 1974. Isso me expôs a alguns desses estudos comparativos e voltei ao Japão em 1978/79. Tive um semestre livre e fui trabalhar no Museu Nacional de Tecnologia, que tinha acabado de ser inaugurado, estava bem vazio naquela época. Me interessei pelo turismo japonês, que era único, com modelos antigos de turismo, muito abundante e bem organizado. Quando voltei aos Estados Unidos, não consegui encontrar ninguém que tivesse escrito sobre turismo japonês. Todo mundo escrevia sobre protestantes e budistas e todas essas coisas. Ninguém escrevia sobre turismo. Então, escrevi um livro chamado To Pray, Pay and Play: the Cultural Structure of Japanese Domestic Tourism (Graburn, 1983) e não consegui publicá-lo nos Estados Unidos. As pessoas diziam: "turismo?!” e achavam que 80 páginas eram demais. Alguns jornalistas diziam: "cortamos umas 20 páginas e publicamos”. Algumas editoras diziam: "transformaremos em 20 páginas e publicaremos". Oitenta páginas é um tamanho muito estranho, mas não sei se poderia escrever mais. Por sorte, eu estive em contato com um homem do Centre des Hautes Études Touristiques, em Aix-en-Provence, uma espécie de organização de estudo de turismo patrocinada pela indústria francesa de turismo. E ele tinha uma editora grande e publicava muito. Ele tinha publicado um artigo sobre museu e turismo. Na verdade, havia conseguido uma pessoa para traduzir para o francês, mas ele disse: "Vou publicá-lo do jeito que está, sem traduzi-lo para o francês.” Então, ele publicou o artigo, que saiu em 1983. Estive lá em 1979 e foi publicado em 1983. Muitas pessoas no mundo usaram esse artigo original sobre a antropologia do turismo japonês e turismo doméstico, enquanto outras que escreveram sobre o Japão moderno e contemporâneo usaram o livro. Claro, foi impresso há muito tempo, mas ainda está nas bibliotecas. Eu tenho observado o turismo japonês ao longo dos últimos 13 anos, retornando com freqüência para lá. E isso expandiu meu interesse também para a China e o turismo doméstico chinês. Estive na China muitas vezes nos últimos 11 anos e eles são muito próximos dos japoneses, mais do que de qualquer outro povo do mundo. Eles 
têm muito em comum e se vistam mutuamente. Assim o Japão é o lugar favorito dos turistas coreanos, o lugar favorito para o turista japonês agora é a China. Costumava ser os Estados Unidos, mas a agora é a China, por causa da abertura do país ao turismo. Eles formam um grupo que engloba $75 \%$ dos turistas japoneses e chineses e os outros $25 \%$ vão para o resto do mundo. Os chineses estão investindo no turismo doméstico porque é algo realmente antigo e de que todo mundo participa; apenas poucas pessoas podem viajar para o exterior. E isso também interessa as relações internacionais de cultura. Uma coisa que aconteceu nos últimos dez anos foi que o turismo seguiu os filmes e os dramas televisivos. Quando a Coréia fez um programa televisivo chamado The Winter Sonata, uma história de amor muito triste, as japonesas amaram. E elas quiseram ir aos lugares onde o filme foi rodado. Eles puseram estátuas de cenas dos amantes se beijando ou dizendo adeus. Parecia ter sido criado um círculo ao redor dessa parte da Coréia para visitar os lugares onde o filme foi feito. E eles pagavam para ir a estes lugares. Surpreendente! Por causa desse sucesso, todas as empresas daquela região perceberam que fazer filmes era a principal maneira de conseguir novos turistas. Até as cidades japonesas pagavam as companhias coreanas para fazer filmes em suas cidades. Uma coisa louca. Houve parcerias entre Hong Kong e Coréia e entre China e Coréia para que as pessoas pudessem visitar esses lugares dos filmes. As pessoas vão ao cinema e querem ver esses lugares. Isto está acontecendo ao redor do mundo, e isso interessa muito às relações de turismo internacional.

Rodrigo Grünewald: E o seu trabalho com museus? Você está interessado em museus e em curadoria?

Nelson Graburn: Desde 1970 tenho sido curador do Museu Hearst de Antropologia. A senhora Hearst, que era uma mulher extremamente lúcida, apoiava o Departamento de Antropologia de Berkeley. Ela patrocinou expedições de arqueologia e comprou coleções enormes no mundo todo e as colocou em Berkeley. Então, eu me tornei o curador e as pessoas começaram a conhecer meu trabalho no museu. Um dia, vieram até mim e disseram que queriam organizar uma exposição sobre as mudanças da arte primitiva ou mundo tribal. Organizamos uma exposição, com um pequeno catálogo, sobre tradições e mudanças, o que talvez tenha sido a primeira exposição no mundo que reuniu ilustrações sobre as mudanças das coleções de museus, como as coisas eram aculturadas... Por exemplo, uma das coisas que fizemos foi reunir uma série 
de cuias de mate, vinda talvez da Argentina, para mostrar o que tinha mudado naquela época. Isso é comercial, mas é étnico. Lembro-me que fotografei as cuias e Larry Dawson, um dos três co-autores que conhecia o museu do direito e do avesso, tinha uma mente ágil para conectar as coisas. E mostramos mudanças nas tradições artísticas de coisas da arqueologia, história, cruzando o Atlântico. Pudemos localizar coisas como os árabes que pegavam desenhos dos persas e levavam para a África, para a Espanha e Portugal. Mais tarde, os espanhóis pegaram esses desenhos e levaram para o México e América do Sul. Os mexicanos pegaram esses desenhos e levaram para o Sudeste dos Estados Unidos, onde as tribos hopi e zuni pegaram e colocaram esses desenhos em suas cerâmicas. Você pode olhar e dizer: "Isto é uma cerâmica hopi." Sim, mas, na verdade, esses desenhos foram localizados com os persas. Claro, as pessoas dizem: "Oh, que maravilhoso! Eles podem retratar animais e pássaros.” Claro que podem, eles copiaram dos persas o modo de fazer isso. Antes da aculturação pelos espanhóis, esses índios nunca fizeram nenhum desenho em cerâmica. Isso mudou entre 1860 a 1880, sob a influência dos espanhóis. De qualquer forma, essa foi uma pequena exposição e um pequeno catálogo. Infelizmente, Larry não tinha bom gosto. Ele imprimiu em papel verde com capas azuis. E era difícil de ler. Foi chamado Traditions in Transition (Graburn; Dawson; Frederickson, 1974). Era muito difícil ler o título na capa, o texto no papel verde. Mesmo assim foi um grande esforço. Isso foi antes da arte turística. Foi baseado no trabalho preliminar que eu tinha feito. Alguns dos artigos eram da publicação da Unesco. Então, eu me tornei o curador e desde então o trabalho mais ativo no museu tem sido organizar as exposições. Estive envolvido em uma série de exposições. Tivemos a maior visitação na exposição de arte nativa, inuit. O governo canadense fez publicidade. Mais tarde, fiz uma exposição na Companhia Comercial Alasca com a coleção que a senhora Hearst nos deu sobre os inuit e os índios do Alasca. Mais tarde, eu organizei uma exposição com meus alunos de pós-graduação. Era principalmente sobre o povo inuit do Canadá e arte nativa canadense. Contamos com uma mulher inuit que nos ajudou na abertura, assistiu às aulas e fez um filme com os estudantes sobre as aulas e a exposição. Ela queria levar o filme para o Ártico e mostrar ao seu povo o que nós fazíamos com aquelas coisas, por que as colecionávamos e colocávamos em museus, para mostrar o quanto os alunos são entusiasmados com aquela cultura. Fizemos o filme e os alunos aprenderam a fazer um filme autobiográfico, que depois foi editado, sonorizado e exibido na televisão. Não faz muito tempo, organizei outra exposição com minha própria pesquisa. 
Usei peças que colecionei ao longo dos anos e uma porção de coisas que usei para pensar sobre as transformações em diferentes países, para pensar sobre expressões pessoais, mudanças técnicas. Em vez de "pesquisa sobre arte”, chamamos de "a arte da pesquisa”. A arte da pesquisa de Nelson Graburn. Não havia um catálogo, mas um artigo escrito por Roz Tunis, que era um curador freelancer com quem trabalhei bastante. Foi publicado na Inuit Art Quarterly [Revista Internacional de Arte Inuit] (Tunis, 2001). Ao lado disso, havia um outro artigo que tinha sido publicado em uma revista pouco conhecida, onde eu coloquei as melhores fotos. Essa foi a última que organizei. Uma outra exposição que estava planejando fazer era uma exposição itinerante sobre arte nativa e Alasca. Não apenas com a coleção da Companhia Comercial Alasca, mas reunindo outras coleções. Havíamos planejado doações e estávamos prontos para iniciar quando nosso diretor se demitiu e não conseguimos encontrar um substituto. Na verdade, era eu quem estava organizando e planejando a exposição, com alguns nativos do Alasca que estavam trabalhando conosco. Queríamos ser co-autores. Ainda estamos pensando sobre isso.

Rodrigo Grünewald: Se você pudesse dividir sua produção acadêmica em blocos, como faria? Blocos como "arte turística e étnica”, “museus” e "organização social”? Como você organizaria esses blocos?

Nelson Graburn: Isso é muito interessante. Diria que, ao contrário de algumas pessoas, eu os disponho paralelamente. Então, em vez de terem um bloco aqui, outro ali e outro lá, a maioria das pessoas constroem tudo em um só bloco, o que é mais complicado e confuso. Eu parei de lecionar e de pesquisar sobre parentesco. Entretanto, a literatura sobre parentesco ajuda a analisar outro fenômeno, como a natureza da herança, porque todos nós baseamos a identidade em pertences. Eu usei os modelos de parentesco para a análise da herança e como as pessoas utilizam o turismo para explicar a herança para a família. Essas duas coisas seguem juntas. E é por isso que, quando ensino, eu não chamo de turismo e arte. Eu chamo turismo e arte moderna, porque os museus estão envolvidos nessa identidade e eles mostram expressões dessa identidade que tem que ser mantida, inclusive por meio de uma série de coisas que as pessoas compram e levam para casa. Essas coisas, na verdade, são inseparáveis. Não sei como isso se chama, mas essa espécie de política de identidade está associada aos museus, aos programas turísticos, à classe. Todas essas coisas estão juntas, e quando eu ensino, mantenho tudo articulado. 
O Japão é um subtema do que faço no turismo. Recentemente passei a me interessar pelo turismo japonês e pelos estrangeiros no Japão. Eles têm diversas vilas estrangeiras e muitos estrangeiros vivendo no Japão. E o país está mudando. Havia alguns estudantes que queriam pesquisar esse tema e eu decidi organizar uma conferência que chamei de "Multiculturalismo no Japão". O meu trabalho foi sobre multiculturalismo em museus e turismo no Japão, mas nós tivemos outros trabalhos sobre outros aspectos do multiculturalismo no Japão, como mulheres imigrantes casando com japoneses, comunidades de fronteira. Trabalhei duro na organização de um livro que resultou dessa conferência e que está para ser publicado. Minha pesquisa sobre o turismo no Japão me levou para outros temas. A própria antropologia tem mudado bastante desde 1960. O tipo de coisa que eu faço agora não existia na antropologia nos anos 1960. Talvez tenha começado nos anos 1970. E todo mundo tem mudado na antropologia também. Então, não inventei as coisas sozinho. Todos nós estamos nos movendo, observando mais os simbolismos, as identidades, as políticas de expressão artística, em vez de fazer coisas mais puristas, como costumávamos fazer, como pensávamos que poderíamos fazer.

Rodrigo Grünewald: Liminaridade parece ser um conceito importante para você, porque desde o seu artigo sobre o Santo Graal (Graburn, 1989) você tem usado esse conceito. Todo o seu trabalho é perpassado pela liminaridade?

Nelson Graburn: Eu acho que uma parte fundamental da vida humana é nos desafiar a encenar outros aspectos liminares de outros palcos na própria vida ou na vida da comunidade ou outro círculo. A liminaridade é, para mim, um fenômeno geral que poderia ser utilizado de diversas maneiras, mas a questão da liminaridade é marcar o que é diferente. É um lugar onde as coisas acontecem. Às vezes, é um ritual reverso, outras um comportamento especial ou diferentes hábitos alimentares. Então, a liminaridade é muito especial e um lugar excitante da vida humana. Penso que isso é universal nos humanos, porque de certa forma concordo com Dennison Nash, que diz que a harmonia envolvida no turismo é ainda encontrada na maioria das sociedades. Impressionou-me o trabalho de Maurice Bloch sobre a natureza selvagem do significado do poder da arte, que foi publicado em 1974 (Bloch, 1974). A arte é o aspecto liminar de outros comportamentos. O mundo visual do artista é o aspecto liminar dessa parte em que você encontra experimentos excitantes, coisas diferentes, como janelas através do ordinário, do comum. E fala sobre outros movi- 
mentos. Ele não os chama de liminaridade, mas fala sobre esses lugares especiais e simbólicos. E eles têm um tipo de estrutura e fornecem diferentes sensações para as pessoas que os experimentam.

Rodrigo Grünewald: Desde o início de seus estudos sobre os turistas, quais paradigmas você destacaria? Quais paradigmas você acha importante?

Nelson Graburn: Eu acredito que o paradigma da liminaridade seja básico. Nós aplicamos a qualquer fenômeno a qualquer hora. Também gosto de alguns trabalhos exploratórios e os estudos sobre turismo e significado... o que o turismo faz pelas pessoas e sua relação com identidade de classe. Estou mais interessado nas pessoas envolvidas do que na área do turismo como tal. Embora, hoje, eu esteja muito interessado na interação entre o turista e a viagem, mas acho que isso leva a uma perspectiva dualista. Começamos a falar sobre $o$ impacto do turismo que era como: "temos comunidades diferentes e o turismo as transforma e homogeiniza”. O turismo é sempre a ação e a comunidade a reação. Esta aqui e o outro lá. Bem, vimos nos estudos de Maurice Bloch que a coisa não é tão simples assim. Quando o turismo chega, não é uma coisa. É um conjunto de várias pessoas com diferentes interesses, vários tipos de turistas. Há as multinacionais e os fornecedores de serviços que os trazem. Então, um conjunto de gente séria com diferentes interesses move essa arena. E, se você vir isso por outro lado, não existe um grupo passivo. Geralmente há um conjunto de pessoas afetadas na área alvo do turismo que têm interesses diferentes, alguns proprietários de terras e prédios. Eles dizem: "Bom, esta excelente oportunidade de negócios.” Mas há outras pessoas que têm que ir embora e outras que não têm nada a fazer diretamente com o turismo, mas continuam vivendo na comunidade e sofrem as conseqüências do turismo como a inflação das terras e dos preços dos alimentos. Por isso, prefiro o modelo que analisa qualquer situação de turismo em termos de pessoas vindo e indo, com diferentes interesses no mesmo fenômeno. É o que aconteceu no turismo. Todos estão tentando se virar na situação. Por isso é que eu gosto de alguns dos trabalhos que o arquiteto e urbanista Rami Daher tem escrito sobre o que aconteceu na Jordânia sobre o desenvolvimento de projetos turísticos. Ele escreveu o melhor livro sobre o Oriente Médio que conheço e trabalhou com o Mike Robinson, em Sheffield. Ele também passou um ano em Berkeley, trabalhando comigo e Nezar Al-Sayyad. Enfim, mudamos do modelo de impacto para o modelo de interesse. 
Rodrigo Grünewald: E em termos acadêmicos, a antropologia tem estado conectada com outras ciências humanas nos estudos sobre turismo? Você acha que em termos acadêmicos a antropologia tem seguido um caminho "solo" ou deveria continuar a dialogar com outras disciplinas?

Nelson Graburn: Na verdade, é útil dialogar com outras disciplinas. Muitas das coisas que lemos foram escritas por pessoas de outras disciplinas. Estamos todos interessados no mesmo tema e em dizer que a negociação entre as partes envolvidas está na cultura. Economistas estão interessados nos estudos culturais, geógrafos e antropólogos estão todos interessados no mesmo fenômeno. Temos que ler uns aos outros. Há no turismo algo que envolve a antropologia e outras disciplinas: a relação entre o local e o global. A antropologia foi além dos estudos de comunidade e mesmo dos estudos de rede. A antropologia está preocupada com os movimentos globais do mesmo modo que outras disciplinas. Na verdade, talvez ela tenha um desempenho melhor nos movimentos globais porque conhece muito bem o local. Os antropólogos estão lendo e utilizando as mesmas coisas que os outros, apenas não têm uma abordagem majoritariamente quantitativa. Fora isso, hoje estou lendo coisas de pessoas que dizem fazer uma nova geografia e a única diferença é que elas enfatizam o espaço mais do que qualquer outra coisa. Acredito que os antropólogos precisam levar em conta o espaço também. Não é preciso ser geógrafo para fazer isso. Eu acho que esses novos geógrafos fazem etnografia. Mas considero um pouco suspeito os estudos culturais feitos por pessoas que não fazem etnografia, por que elas acabam utilizando modelos preestabelecidos para analisar as coisas e as vêem a partir de posições políticas. Elas podem estar certas ou erradas, mas elas realmente não o sabem, uma vez que nunca se fizeram essas perguntas. Desconfio que quando nós usamos materiais, posições e livros dos estudos culturais podemos ser levados a conclusões não muito seguras. Os antropólogos podem achar alguns estudos socioculturais brilhantemente corretos ou podem achar incompletos. Não estamos mais sozinhos nos estudos sobre turismo, artes turísticas e museus. Não podemos mais usar nossos próprios paradigmas e conceitos. Devemos ser capazes de compreender os conceitos de outras áreas também. Por outro lado, vejo que as pessoas estão aderindo à antropologia, pensando que estão fazendo etnografia. A antropologia se tornou muito bem sucedida para quem quiser usá-la. Por exemplo, a Sociedade Urbana de Etnografia que tem uma revista chamada Ethnography, em sua lista de membros do conselho, apenas três, entre 20, são antropólogos. Estamos recor- 
rendo uns aos outros e temos sido bem sucedidos. Um dos problemas com esse sucesso é que algumas pessoas confundem nossos instrumentos com os conceitos. Quando os estudantes chegam aos meus seminários, costumo dizer-lhes que eu nunca tive um núcleo de estudantes de antropologia, porque os meus estudantes geralmente são da geografia, dos estudos étnicos, da matemática, da arquitetura, dos estudos italianos, da música, etc. Então eles aprendem que esses conceitos e modos de pensar têm que ser adquiridos no trabalho de campo. Sei que alguns antropólogos fazem muitas declarações e constroem paradigmas baseados em pouco trabalho de campo, mas quando eles fazem isso, estão fazendo o mesmo que os outros fazem. Eu cheguei à idéia do turismo como uma jornada quando percebi que pelo turismo se torna conhecido o que era secreto. Quando eu estava no Japão, muito depois disso, estava sendo entrevistado no rádio, ao vivo, e o jornalista disse para mim: "Bem, você escreveu em 1976, o que foi publicado em 1977, e você esteve no Japão em 1974. Você deve ter chegado à essa idéia porque você esteve no Japão.” E eu disse: "Não, não foi bem isso. A idéia se encaixa ao Japão muito bem, mas, na verdade, eu pensei nisso independentemente de ter vindo ao Japão.” Ele não sabia o que dizer no rádio, ao vivo, uma vez que a minha visita ao Japão não me tinha dado o insight para essa teoria sobre o turismo. Às vezes, também pegamos nossas idéias e as testamos. Por exemplo, foi uma etnografia comparativa que me levou ao estudo da arte turística. Então, se eu tivesse observado apenas um dos contextos, não teria tido o interesse de escrever sobre isso porque eu vi a manipulação do significado sobre as coisas feitas pelos inuit, quando eu observei os comerciantes e os museus. Isso foi o ponto de partida para fazer minha pesquisa.

Rodrigo Grünewald: Agora você está morando em Berkeley e tem um emprego na Inglaterra...

Nelson Graburn: Sim, apenas parcial. Estarei lá apenas por três semanas a cada período.

Rodrigo Grünewald: Onde?

Nelson Graburn: Na Universidade Metropolitana de Londres.

Rodrigo Grünewald: E quais são os seus projetos lá? 
Nelson Graburn: Bem, você se refere a como isso se relaciona com o que eu tenho feito?

\section{Rodrigo Grünewald: Sim.}

Nelson Graburn: Bem, estou querendo fazer menos [risos]. Ainda não aconteceu nada. Eu não sei que efeito terá, porque eles me disseram que eu não precisaria dar aulas. Tenho que ajudar as pessoas em suas pesquisas.

Rodrigo Grünewald: Em artes, turismo...

Nelson Graburn: Será em turismo e artes, porque as pessoas que me contrataram estão num departamento chamado "Linguagem e Turismo Internacional”, ou algo do tipo. É uma espécie de departamento de antropologia para pesquisar turismo, herança e cultura naquela universidade. Eles têm vários antropólogos que estudam turismo e são bem famosos. Michael Hitchcock estuda a Indonésia, turismo e souvenirs. Há também Raoul Bianchi, um membro jovem, que estuda turismo e relações de trabalho, e Tom Selwyn, que estuda desenvolvimento de turismo.

Rodrigo Grünewald: E sobre sua vinda ao Brasil? Como foram seus estudos sobre turismo no Brasil? E as pessoas aqui?

Nelson Graburn: Bem, eu fiquei muito impressionado com as pessoas que eu conheci no Brasil, especialmente na Reunião de Antropologia do Mercosul (RAM) ${ }^{6}$ Me surpreendi com a quantidade de pessoas interessadas e com o número de estudantes que está fazendo pesquisas e relatórios. A antropologia me pareceu muito viva e excitante no país e os antropólogos brasileiros estão tendo muito sucesso. Talvez eles não sejam mais importantes do que em outros países, mas é maravilhoso que o Brasil esteja cooperando com outros países. Obviamente, o Brasil tem contribuições importantes para a antropologia atual e há muitas coisas interessantes em termos de mudanças sociais, etnicidade, ra-

6 Nelson Graburn refere-se aqui à VII Reunião de Antropologia do Mercosul, que se realizou em Porto Alegre, no período de 23 a 26 de julho de 2007, na qual ele participou como conferencista na mesaredonda “Antropologia do Turismo” e no simpósio sobre “Antropologia do Turismo”. 
ças múltiplas e tudo o que você puder pensar a respeito. De algum modo, o Brasil é um paraíso antropológico. Fico feliz em saber que os antropólogos estão sendo patrocinados pelo governo porque, como você sabe, em alguns lugares do mundo a antropologia não tem sido patrocinada pelo governo. Fiquei mais feliz ainda em ver o considerável intercâmbio entre antropólogos brasileiros e europeus. Encontrei lá também vários antropólogos americanos, além do Brasil, Argentina, Chile e Peru. O Brasil é um terreno antropológico muito rico. Não conheço muitas publicações brasileiras, mas as que eu tive a oportunidade de ver são muito boas. Felizmente pude lê-las e apreciá-las. Também fiquei impressionado com a revista Horizontes Antropológicos e com alguns livros produzidos por Margarita Barretto, Caleb Faria Alves, você(Rodrigo Grünewald), Carlos Alberto Steil e o Wallace de Deus Barbosa. É uma boa tradição antropológica que ainda acredita em dados, pesquisa e que não está amarrada a modelos antiquados. Seu próprio trabalho está desafiando os modelos de outras pessoas. É uma ruptura. Você está propondo coisas que outras pessoas devem começar a observar. É por isso que estou feliz em divulgá-lo e vou continuar a fazê-lo em inglês, francês, japonês, não sei. O Brasil é um ótimo lugar para ser divulgado no mundo da antropologia. A antropologia do país ainda está pouco presente na Ásia, pelo que eu sei, e há muitas razões para isso. É difícil chegar lá, leva muito tempo, de modo que é difícil para os acadêmicos brasileiros irem aos encontros na Ásia. Mesmo quando eles conseguem bancar, leva muito tempo para chegar, pois não há vôos diretos. Mas o Brasil tem muito a fazer e sei que há bons instrumentos e relações antropológicas para isso. Sei de brasileiros que estão fazendo pesquisa no México, mas não sei se há mexicanos fazendo pesquisa no Brasil. A idéia de uma troca igualitária é maravilhosa. Detestaria ver que alguém vai para algum lugar e volta sem conhecer os acadêmicos locais. Sei que essa é uma acusação comum contra os Estados Unidos. Os acadêmicos brasileiros têm muito a dizer e desejam conhecer o que outras pessoas estão fazendo. Também conheci muitos estudantes interessantes. Tive sorte em conhecer você em sala de aula. Talvez você tenha criado um interesse específico em antropologia, que chamou a atenção dos estudantes. Acho que está acontecendo um movimento antropológico maravilhoso no Brasil. Acho que o país tem graves problemas de pobreza, relações raciais e saúde também, mas a antropologia pode ajudar a pensar sobre isso. Talvez os antropólogos tomem a dianteira e levem isso bastante a sério.

Rodrigo Grünewald: Quais são os seus projetos de agora em diante? 
Nelson Graburn: No momento, estou observando o que está acontecendo. Estou escrevendo um texto que será a base para uma palestra que vou apresentar na universidade e também de um capítulo para o livro organizado por Margarita Barretto, que será traduzido para o português. Como eu disse, estou escrevendo sobre a exposição que estamos planejando fazer sobre o Alasca e as artes nativas. Ainda não escrevi a maioria do material. Estou reunindo algumas fotografias vindas do Alasca e de Berkeley. Tenho que escrever o texto e já fiz uma versão que não depende das ilustrações. Bem, tenho ainda dois outros textos para terminar, um para os Estados Unidos e outro para a Inglaterra. Também tenho que escrever um texto para a reunião da Associação Americana de Antropologia, que se realizará no final de novembro [2007] e estou muito animado, porque a sessão é sobre empreendedores culturais. Não sei o que está acontecendo no Brasil, mas, no resto do mundo, na segunda metade do século XX, existiram pessoas que fizeram conexões entre diferentes partes do mundo e fizeram as coisas acontecerem. Um dos principais exemplos é Jim Thompson, que foi um americano que decidiu, depois da Segunda Guerra Mundial, ir para a Tailândia ressuscitar a indústria da seda. Ele levou seda para os amigos em Nova Iorque, trabalhou com os produtores na Tailândia e criou uma das maiores indústrias de seda do mundo. Isso aconteceu muitas vezes com o comércio de arte nativa e inuit, a arte moderna asiática e a arte africana. Não sei sobre o Brasil, mas esse poderia ser o papel de empreendedores que fazem as coisas locais se tornarem algo de que todo mundo se orgulha. Fizeram um projeto para voltar ao passado, e disseram: "Essas coisas que eu descobri fazem parte da herança dessas pessoas.” Então, vou escrever um texto sobre Jim Houston, que promoveu a arte inuit. ${ }^{7}$ Espero que outras pessoas escrevam sobre isso também. Sempre quis fazer um livro sobre isso. Sei que existem trabalhos assim na Indonésia. Não sei quando serão publicados, mas estou aguardando.

Rodrigo Grünewald: Você gostaria de dizer algo sobre sua vida e trabalho que eu não perguntei?

Nelson Graburn: Bem, eu penso que fui exaustivo. Gostaria apenas dizer que a vida é interessante, que nunca deixa de ser interessante e, de algum modo,

\footnotetext{
Cross-Cultural Magicians: Entrepreneurs of Art and Heritage in the late $20^{\text {th }}$ Century. Texto apresentado na Sessão "Heritage Entrepreneurs”, da Reunião da Associação Americana de Antropologia, em Washington D.C., em novembro de 2007.
}

Horizontes Antropológicos, Porto Alegre, ano 14, n. 29, p. 341-368, jan./jun. 2008 
fica cada dia melhor. A vida é tão curta... Às vezes, leva-se muito tempo para aprender algumas coisas que a gente aprecia quando conquista. Há, por outro lado, algumas coisas que eu aprendi a fazer, que aprecio agora, e que gostaria de ter aprendido antes. Penso que existe uma relação estreita entre a vida pessoal e a profissional e isso é divertido e vale a pena explorar. Não creio que as pessoas devam separar as coisas, dizendo, por exemplo, que não há nenhuma relação entre sua infância e sua vida profissional. Ambas se relacionam mutuamente e estão interligadas. Na antropologia, não deveria haver relutância em admitir isso. Por que temos de fingir que estamos fazendo uma ciência desconectada? Não estamos. Estamos lidando com seres humanos e somos humanos também. Então acho que essa é uma lição importante. Há um livro escrito por uma antropóloga inglesa, Judith Okely, chamado Own or Other Culture (Okely, 1996), que é uma autobiografia em que ela fala sobre como sua vida foi afetada pelos trabalhos que ela fez. É um livro muito inspirador. Gosto do fato de eu ter tido muitas experiências na China. Minha mulher diz: “Os idosos se dão bem lá, porque todo mundo presta atenção.” Bem, se eu fosse mais jovem e não tivesse mulher talvez eu fosse mais tímido ou algo do tipo, mas eu gostei muito do meu trabalho com as pessoas na China. Estudantes e professores, as pessoas em geral, são muito gentis, abertas. Elas querem conhecer você e levá-lo para fazer pesquisas. Acho que o Japão tem mais problemas do que a China. Eles têm problemas em ter filhos, têm problemas com os filhos que têm. As crianças japonesas não querem crescer, querem ser adultos instantaneamente. As mulheres japonesas não querem se casar com homens japoneses, ou, quando se casam com eles, não querem ter filhos. Eu gosto do Japão, mas acho que muita coisa está indo mal lá. E eu não vejo o mesmo na China. Não estou dizendo que prefiro a China, mas vejo esse país numa condição mais feliz. Fiquei surpreso por gostar tanto da China.

Rodrigo Grünewald: No que você acha que a antropologia do turismo e a antropologia de modo geral ajudariam os empreendedores a desenvolver o turismo em certos lugares?

Nelson Graburn: A antropologia poderia fazer várias coisas. Não sei se os empreendedores e o governo acham que os antropólogos possam ajudar. Mas, algumas vezes, eles podem. Penso que os antropólogos têm consciência de que escolhem as pessoas que querem ajudar. Eles não ajudam a todos. Por exemplo, há um movimento chamado pró-turismo. Nós não dizemos que o turismo pode aumentar o emprego, a remuneração, mas dizemos quem é benefi- 
ciado pelo turismo. Temos que dirigir o turismo para um segmento da população, mas isso não cabe apenas aos antropólogos. Os geógrafos e ativistas têm trabalhado nisso. Podemos ajudar as pessoas a compreender para onde elas estão indo e a projetar as coisas para que elas entendam e apreciem mais o lugar de destino. Os antropólogos podem, como no caso de Edward Bruner, na Indonésia, trabalhar como antropólogo e como guia turístico. Ele conhece a Indonésia e conhece o turista. Então acredito que os antropólogos estão numa posição muito boa, desde que escolham o que desejam fazer.

Rodrigo Grünewald: Bem, muito obrigado e eu desejo que você se divirta bastante...

Nelson Graburn: Estou feliz por estar aqui em Buenos Aires, embora não saia muito. Ainda tenho trabalho a fazer, mas encontrei pessoas aqui, como o jovem casal que me apresentou à universidade que é dirigida pelas mães dos desaparecidos. Eles têm um café e um restaurante na universidade, um tipo de organização de ensino e treinamento, patrocinada por vários empresários que visam publicidade. É por isso que eles patrocinam as mães daqueles que desapareceram. $^{8}$

Rodrigo Grünewald: É um tipo de turismo?

Nelson Graburn: Sim, todo mundo quer ir e ver. É um tipo de organização bastante antiquado, com uma porção de coisas no chão, muitos livros que as pessoas podem pegar, biblioteca livre. É como voltar aos anos 1960.

Traduzido do inglês por Adriana de Oliveira. Revisão técnica de Rodrigo Grünewald e Carlos Alberto Steil.

8 Trata-se de um jovem casal, produtores de filmes, conhecidos de Nelson Graburn, que ele encontra em Buenos Aires. Na ocasião eles estavam fazendo um filme sobre imigrantes chineses em Buenos Aires, e o entrevistaram para o filme sobre diáspora chinesa. A entrevista aconteceu num café da Universidade Popular das Mães da Praça de Maio: Universidade da Luta e Resistência. Essa universidade está situada na rua Hipólito Irigoyen, 1584, Buenos Aires (http://www.madres.org/univupmpm/ univumpm.asp). 


\section{Referências}

ASPELIN, Paul L. The anthropological analysis of tourism: indirect tourism and political economy in the case of the Mamainde of Mato Grosso, Brazil. Annals of Tourism Research, v. 4, n. 3, p. 135-160, 1977.

BLOCH, Maurice. Symbols, song, dance and features of articulation: is religion an extreme form of traditional authority. European Journal of Sociology, v. 15, p. 55-98, 1974.

GRABURN, Nelson H. H., The Eskimos and airport art. Transaction, v. 4, p. 28-33, 1967.

GRABURN, Nelson H. H. Ethnic and tourist arts: cultural expressions from the fourth World.: Berkeley: University of California Press, 1976.

GRABURN, Nelson H. H. To pray, pay and play: the cultural structure of Japanese domestic tourism. Aix-en-Provence: Centre des Hautes Etudes Touristiques, 1983. (Les Cahiers du Tourisme, Serie B, Numero 26).

GRABURN, Nelson H. H. Tourism: the sacred journey. In: SMITH, Valene (Ed.). Hosts and guests: the anthropology of tourism. $2^{\text {nd }}$ ed. Philadelphia: University of Pennsylvania Press, 1989. p. 21-36.

GRABURN, Nelson H. H.; DAWSON, Larry; FREDERICKSON, Vera Mae. Traditions in transition: culture contact and material change. Berkeley: Lowie Museum of Anthropology, 1974.

LIPS, Julius. The savage hits back. New Haven: Yale University Press, 1937.

MACCANNELL, Dean. The tourist: a new theory of the leisure class. New York: Scocken Paperbacks, 1976.

OKELY, Judith. Own or other culture. London: Routledge, 1996

TUNIS, Roslyn. The art of research: Nelson Graburn and the aesthetics of Inuit sculpture: Co-Curated by Roslyn Tunis and Nelson Graburn. Inuit Art Quarterly, v. 16, n. 3, p. 24-29, 2001. 